\title{
Application of Law Number 2 Year 2012 Regarding Land Procurement for Development For General Interest in The Protection of Human Rights to Victims of Searching (Case Study Procurement of Land Related to Sodetan Inlet River Ciliwung, Bidara Cina, East Jakarta)
}

\author{
Dwi Andayani Budisetyowati ${ }^{1}$ \\ \{dwib@fh.untar.ac.id $\left.{ }^{1}\right\}$ \\ Faculty of Law Tarumanagara University, Jakarta,Indonesia ${ }^{1}$
}

\begin{abstract}
Undang-Undang/ Law no. 5 of 1960 concerning Basic Agrarian Regulations explains that if land has a social function, it means that for the public interest the rights to land are property rights, building use rights, use rights or use rights. land ownership can be revoked. But the question is what is appropriate "for the public interest according to law". In order not to experience multiple interpretations in society, Law no. 2 of 2012 concerning Land Acquisition for Development for Public Interest. One of the interesting cases is the case of the revocation of ownership rights / property rights committed by the DKI Jakarta Provincial Government to the people of Bidara District, East Jakarta on behalf of the public interest due to the development of Law No. 2 of 2012 is a regulation that regulates the related stages that must be passed by parties wishing to carry out the eviction action, so through this research the researcher examines the implementation of the law in order to provide protection of human rights. This research is a legal research with a normative doctrinal approach through research. However, in conducting research, the researcher also conducted interviews with the parties involved in this case.
\end{abstract}

Keywords: Land Procurement, Human Rights, Public Interest.

\section{Introduction}

The land is as a gift of God Almighty to the nation of Indonesia is one of the main sources for the survival and livelihood of the nation of all time in achieving the greatest prosperity of the people are divided equally and equitably. So the land is to be cultivated or used for the fulfillment of real needs. In connection with the provision, allocation, control, use and maintenance it needs to be regulated to ensure legal certainty in the control and utilization as well as legal protection for the people, especially the farmers, while maintaining the sustainability of its ability to support sustainable development activities. Land within the territory of the Republic of Indonesia is one of the main natural resources, which in addition to having deep inner value for the people of 
Indonesia, also serves very strategically in meeting the needs of the country and the people who increasingly diverse and increasing, both at the national level and in relation to the world International. ${ }^{1}$

Indonesia as a sovereign country has a land-related or agrarian law regulated in Article 33 Paragraph (3) of the 1945 Constitution of the Republic of Indonesia, which states "Earth and water and natural resources contained therein shall be controlled by the state as much as possible for the welfare of the people." Based on Article 33 paragraph (3) it can be interpreted if the land that is part of the earth is actually controlled by the state for the greatest prosperity of the people. The phrase "controlled by the state" pursuant to Decision of the Constitutional Court in the legal considerations of Decision Case Oil and Gas Law, Power Law and Water Resources Law (UU SDA) interpret "state controlling rights (HMN)" not in the meaning of the state has, but in the sense that the state just formulate the policy (beleid), make arrangements (regelendaad), manage (bestuursdaad), manage (beheersdaad), and supervise (toezichthoundendaad). ${ }^{2}$

Nowadays the need for land for development is increasing especially by countries that are required to always provide land so that the role of the state as a "regulator" sometimes undertakes activities of "land acquisition for public purposes" on a small scale or large scale, when in its implementation facing the state with groups of people who do not want the land used as the object of development by the state. therefore, the role of the state as a regulator is very important, especially in regulating the rights of the state in the procurement of land in the public interest so as not to violate the rights of the community and to regulate the extent to which the rights of the people can defend their land if procured land for the common good.

In addition to development factors, the increasing number of population is higher, while the state of fixed and limited land causes the population's interest to land becomes high. Thus, humans increasingly intensify their efforts to get land to achieve their respective goals in exploiting the land. Likewise the state through the government which sometimes in practice if not supervised in certain ways, then the procurement of land can be deviated from the provisions of applicable legislation so that the legal rights of marginalized communities.

Actually, based on the prevailing laws and regulations, the government has the authority to procure land for public interest based on the principle that all land rights are functioning socially as regulated in Article 6 of the Basic Agrarian Law (continuously referred to as UUPA) determines: "All rights to land are functioning socially". The explanation of Article 6 is as follows:

"The right to any land which is present to a person, it is not justifiable that his land will be used (or not used) solely for his personal interests, especially if it causes harm to society. The use of land must be adapted to the circumstances and the nature of the rights, to the benefit of the well-being and happiness that has it and also the benefit of society and the state, but in that case the provision does not mean that the individual interests will be pushed entirely by the public interest. The Basic Agrarian Law also takes into account individual interests. The interests of society

\footnotetext{
${ }^{1}$ Boedi Harsono, Menuju Penyempurnaan Hukum Tanah Nasional, cet. 3., (Jakarta: Universitas Trisakti, 2007), hal.3.

${ }^{2}$ Salah Satu Putusan Mahkamah Konstitusi Nomor 002/PUU-I/2003, tertanggal 21 Desember 2004, terkait Sumber Daya Alam (SDA).
} 
and the interests of the individual must balance each other, to the ultimate achievement of the ultimate goal of prosperity, justice and happiness for the people as a whole."

Based on the explanation of Article 6 of the above Law, it can be concluded that every right of a person belongs to the rights of the public (public). ${ }^{3}$ When Article 6 of the UUPA is scrutinized, there are several things that can be viewed as the nature of the social function of property rights to land which is intended as an affirmation of the subject of limitation of individual freedom. The nature of social functions include as following: ${ }^{4}$

1. The use of land shall be in accordance with the circumstances of the land, the nature, and the purpose of granting the right so that according to the UUPA the abandoned land is contrary to the social function;

2. Land use shall be in accordance with the plan established by the government;

3. If the public interest requires the destruction of the interests of the individual to suffer a loss then it shall be compensated for him;

4. Land is not a commodity of commerce so it is not justified to make land as the object of speculation. "

Post-reform in 1999, although the UUPA from that date has not been changed by the legislator, but on the consideration of protection the law against constitutional right / human rights guaranteed in the 1945 Constitution of the Republic of Indonesia concerning the protection of property rights of the citizens so that the state / government is not easy to seize land ownership rights citizens on behalf of the public interest, then the law was enacted. Law no. 2 of 2012 on Land Procurement for Development for the Public Interest mentioned in Article 1 sub-article 2 in the Procurement of Land is an activity of providing land by providing compensation that is fair and fair to the party entitled. Furthermore, it is mentioned that if the government wishes to procure the land as mentioned in Article 13, it must perform 4 (four) stages: first, planning stage, second, preparation stage, third, implementation and fourth, delivery of nasil. If these stages are not performed, then the citizen who feels aggrieved by the issuance of a location determination letter related to land acquisition for the public interest can file a lawsuit to the State Administrative Court to oppose the procurement of the land.

As in the case of the Bidara Cina Sub-District, Jatinegara Sub-district, which is one of the sources by the authors in writing this research, the case where some East Jakarta ladies filed a State Administration Lawsuit at the Jakarta State Administrative Court on the basis of wanting to cancel the Decision Letter Location Number 2779 Year 2015 issued by the Governor of DKI Jakarta related to the establishment of Sodetan Inlet by the Provincial Government of DKI Jakarta on the basis of public interest. According to the citizens of the Bidara Cina, East Jakarta, the process of making the Decision Letter of Location Determination has actually violated Article 13

3 AP. Parlindungan, Bunga Rampai Hukum Agraria Serta Land Reform, (Bandung: Mandar Maju, 1994), hlm. 87.

${ }^{4}$ Yusriadi, Industrialisasi\&Perubahan Fungsi Sosial Hak Milik Atas Tanah, (Yogyakarta: Genta Publishing, 2010), hlm. 32. 
letters (a), (b), (c) and (d) Law Number 2 Year 2012 on Stipulation of Location for Development in the Public Interest related to the Provincial Government of DKI Jakarta has never undertaken any planning activities such as showing the project planning document, then never socializing / notification to the community related to the activities of the inlet Sodetan project and never giving compensation, so based on Act No. 2 of 2012 the public filed a lawsuit of State Administration in the State Administrative Court of Jakarta. ${ }^{5}$

The lawsuit in Jakarta's administrative court has been terminated by Decision Number: 59 / G / 2016 / PTUN-JKT which won the citizens of East Jakarta's Bidara Cina. when examining the legal considerations of the judges who hear the case, the panel of judges concludes that if the location determination done by the Governor of DKI Jakarta is not in accordance with the legal procedure pursuant to Article 13 (a), (b) (c) and (d) No. 2 of 2012 and Presidential Regulation No. 71 of 2012, especially not the implementation of procedures starting from the preparation stage until the stage of delivery of the results of the compensation so that the judge caused the decree was canceled. Based on the legal considerations, it can be concluded that the procedures for determining the location for development in the public interest must fulfill the requirements stipulated by Law Number 2 Year 2012 on the Determination of Location for Development in the Public Interest.

Therefore, based on the above matters, the government in carrying out development activities by displacing or eliminating the ownership rights of citizens' land on the grounds of the public interest, it is necessary to pay attention to the provisions contained in Law No. 2 of 2012 as legal protection law constitutional rights / human rights of every citizen of his or her ownership rights regulated in the 1945 Constitution of the State of the Republic of Indonesia in which the state or government cannot repeal such ownership in an arbitrary manner. So in order to apply the principle of prudence in conducting land procurement activities conducted by the government, the researcher in this paper tries to make a paper related to "Implementation of Law No. 2 of 2012 on Land Procurement for Development for Public Interest in the Protection of Human Rights against Victim Eviction (Case Study of Land Procurement Related to Sodetan Inlet Ciliwung River Development, East Jakarta Bidara Cina)."

\section{Problems}

Based on the description put forward in the introduction, the researchers want to highlight some of the issues related to the writing of this article are:

1. How is the application of Law Number 2 Year 2012 on Land Procurement for Development in the Public Interest in order to provide Human Rights Protection against Victims of Eviction / release of the land (ownership rights)?

\footnotetext{
${ }^{5}$ Wawancara langsung dengan Resa Indrawan Samir, SH, MH selaku Kuasa Hukum Masyarakat Keluarahan Bidara Cina, Jakarta Timur tertanggal 15 Februari 2018.
} 
2. What are the legal considerations of the judges of the Jakarta State Administrative Court Decision Number 59 / G / 2016 / PTUN-JKT so that the Determination of Location for Development in the Public Interest by the Provincial Government of DKI Jakarta is canceled?

\section{Method Of Writing}

This research is a legal research with doctrinal approach that is normative. ${ }^{6}$ As for which can be made object in research with doctrinal approach that is normative this is data in the form of primary material and material of secondary law and tertiary law material.

Data collection method to be used in this research is through library research, which is data collection method (legal material) by searching, recording, inventorying, studying books, literatures, legislation, previous research results, and documentation relating to the problem under study and not remain unlimited as well how to conduct direct interviews with related parties relating to issues that are addressed such as Observers of Women, Non-Governmental Organizations and Experts in the field of Law and Politics.

The data analysis conducted in this study was conducted with more qualitative approach that revealed the data (legal material) as much as possible so that the issues to be rise more transparent. The qualitative approach allows researchers to elaborate the data obtained comprehensively and the description results become more accountable.

\section{Theory}

\subsection{Land Ownership Rights}

In various literatures, rights can be interpreted as something that we can be cursed because it is absolutely ours. Rights in the law are identical with human rights (human rights) which means existed since human beings are born, because the right is inherent since the existence of man himself. ${ }^{7}$ Historically, as the natural rights theory proposed by John Locke in the late XIV to XIIV, there are 3 (three) inalienable rights and are fundamental rights which include the right to life, the right freedom (liberty) and property right (prosperity). ${ }^{8}$

Prosperity one of them is related to "land ownership (property)" which means that based on it is one of the fundamental rights that cannot be revoked which, as the right is a negative right to realize it the state must be silent, not performing acts or in a passive state. Accordingly, the state cannot automatically take arbitrary deprivation of property rights.

\footnotetext{
${ }^{6}$ Soerjono Soekanto \& Sri Mamudji, Penelitian Hukum Normatif Suatu Tinjauan Singkat, (Jakarta: Rajawali, 1990), Hal. 15.

${ }^{7}$ Mahrus Ali dan Syarif Nurhidayat, "Penyelesaian Pelanggaran HAM Berat In Court System dan Out Court System”, (Depok: Gramata Publishing, 2011), hal. 1.

${ }^{8}$ Ibid., hal. 3 .
} 
In Indonesia, the protection of property rights is regulated in Article 28G Paragraph (1) of the 1945 Constitution of the Republic of Indonesia, which states that "everyone is entitled to the protection of property under his control", meaning that if the property is the right of ownership of the land, the right shall be protected by law. then also protection of property rights is regulated in Law no. 39 of 1999 on Human Rights in Article 36 paragraph (2) stating "no one shall be deprived of his property arbitrarily and unlawfully."

However, within the right of ownership there is a right of ownership by the state which is based on the "right of control of the state" as stipulated in Article 2 Paragraph (2) of the Law on the Law "On the basis of Article 33 Paragraph (3) of the 1945 Constitution and matters as referred to in Article 1, earth, water and space, including the natural wealth contained therein at the highest level is controlled by the state as the power organization of the whole society ". From the latter sense, the state is authorized to determine the rights to land which may be owned by and or provided to individuals and legal entities that meet the specified requirements. Then, based on the Mastering Right of the state as meant in Article 2, there shall be established various kinds of rights on the surface of the earth called land, which may be given to and possessed by persons, either alone or together with other persons and bodies, legal entities as stipulated in Article 16 paragraph (1) of BAL, which are among others:

a) Right of Ownership;

b) Cultivation Rights;

c) Building rights;

d) Right to Use;

e) Right of Lease;

f) Right to Open Land;

g) Rights to Collect Forest Products;

h) Other rights not covered by the above rights to be determined by law and temporary rights referred to in Article 53.

The above mentioned temporary title rights are further stipulated in Article 53 paragraph (1) stating that: "Temporary rights as referred to in Article 16 paragraph (1) letter h, are Payable Rights, Business Rights for -Results, Right of Ride and Right of Lease of Agricultural Land shall be governed to limit its properties which are contrary to this law and the rights shall be abolished within a short time."

A person or legal entity that owns a right to land, by the UUPA is obliged to do or actively pursue it and must also maintain including increase fertility and prevent damage to the land. then in addition, the BAL also requires that the right to land owned by a person or legal entity should not be used solely for private interests arbitrarily regardless of the interests of the general public or in other words all rights to such land shall have a social function as well as is stipulated in Article 6 of the BAL which states that "all rights to land have a social function". However, the social function of the land concerned and does not pour the legal rights of the people and should not be done arbitrarily.

\subsection{Land Ownership Rights by the State}


In principle, the definition of "land rights by the state" is not mentioned in the various laws and regulations in Indonesia. so far against this definition only refers to Article 33 Paragraph (3) of the 1945 Constitution of the Republic of Indonesia, so that it allows the right to control land by the state interpreted on various understandings, depending on the angle of the field and interpreting the meaning even though the Constitutional Court ${ }^{9}$ has interpreted the meaning of Article 33 Paragraph (3) of the 1945 Constitution namely the meaning of "controlled by the state" which is to impose a policy (beleid) and the action of bestuursdaad, regelendaad, supervision (toezichthoudensdaad) to all branches of production branch for the purpose of the greatest prosperity of the people.

Whereas when referring to Article 2 paragraph (1) UUPA which specifically gives understanding of the right to control over the land that is the state is given the authority to:

a. Manage and administer, designate, use, stock and maintenance;

b. Determine and regulate the rights that may belong to (part of) the earth, water and space;

c. Determine and regulate the legal relationships between persons and legal acts concerning earth, water, and space.

So philosophically from the meaning of the right to control land (agrarian) by the state that gives authority to the state to regulate the utilization of rights to land including those controlled by the community. This means that the status of the state in managing and regulating the rights to community land associated with the position as ruler not as owner. For the understanding between being "possessed" possesses juridical consequences as having occurred before the coming into effect of the UUPA. The meaning possessed has the same consequence with the meaning of domain principle in the Dutch colonial era. So that people in this concept no one can have property rights, but only the right to use. Thus it would be contrary to the principle of customary law as the basis of the enactment of the agrarian law (recall article 5 UUPA).

Finding the source and task base for the state's authority in performing its state duties on the state's ownership of land is not the concept of modern state law. Rather it is the long-abandoned conceptions of the laws of the feudal state, both in practice and in legal theory. ${ }^{10}$

Based on that opinion, the state of Indonesia as a modern legal state recognizes the right of state control in order to carry out direct legal relations between the state and the earth, water and space as interpreted by Notonegoro ${ }^{11}$ which establishes the existence of three kinds of relationships as follows:

a. The State as subject, given the position not as an individual but as a state. Thus, the state as a state body, the body publiekrechtelijk. In this form the state does not have the same status as the individual.

b. The State as an object, likened to an individual so that the relationship between the state and the earth and so on is "equal" with the individual right to the land.

${ }^{9}$ Op. Cit, Putusan Mahkamah Konstitusi Nomor 002/PUU-I/2003, tertanggal 21 Desember 2004.

${ }^{10}$ Boedi Harsono, Hukum Agraria Indonesia Sejarah Pembentukan Undang-Undang Pokok Agraria, Isi dan Pelaksanaannya, (Jakarta: Jembatan, 2005), hal. 268.

${ }^{11}$ Ida Nurlinda, Prinsip-Prinsip Pembaharuan Agraria Perspektif Hukum, (Jakarta: Rajawali Press, 2009), Hal. 55-56. 
c. The relationship between the "direct" states with the earth and so on is not an individual subject and not in its position as a possessing country, but as a state which is the personification of all the people so that in this concept the state cannot be separated from the people. The state is only the founder and supporter of the unity of the people.

\subsection{Land Procurement for the Public Interest}

According to Imam Koeswahyono the procurement of land is a legal act undertaken by the government to acquire land for certain interests by providing compensation to the owner (either natural or legal entity) of the land according to certain nominal procedures and magnitudes. ${ }^{12}$ Meanwhile, according to Boedi Harsono, the procurement of land is a legal act in the form of releasing the legal relationship that originally existed between the holder of the rights and the land required by giving rewards in the form of money, facilities or other through consultation to reach agreement between landowners and parties in need. ${ }^{13}$

Whereas when referring to existing legislation, the term land acquisition is used firstly in Presidential Decree No. 55/1993 on Land Procurement for the Implementation of Development for Public Interest in the provision of Article 1 number 1 of land procurement is defined as follows: land."

"Land procurement is any activity to obtain land by providing compensation to the right to the

Then the definition of land acquisition is changed again in the provisions of Article 1 number 3 of Presidential Regulation No. 36 of 2005 on Land Procurement for the Implementation of Development for the Public Interest namely:

"Land acquisition is any activity to obtain land by providing compensation to those who relinquish or deliver land, buildings, plants and objects related to the land or by revocation of land rights."

However, this definition of land procurement is criticized by the public for confusing the concept of land procurement with the revocation of rights. The definition of land procurement is then amended in Presidential Regulation No. 65 of 2006 on Amendment of Presidential Regulation No. 36 namely:

"Land acquisition is any activity to obtain land by providing compensation to those who relinquish or deliver land, buildings, plants and objects related to the land."

In 2012 the government enacted Law No. 2 of 2012 on Land Procurement for Development for Public Interest. The provisions of Article 1 point 2 define the land acquisition as follows:

"Land acquisition is the activity of providing land by providing fair and fair compensation to the rightful parties."

${ }^{12}$ Imam Koeswahyono, Melacak Dasar Konstitusional Pengadaan Tanah Untuk Kepentingan Umum (Artikel, 2008), hal. 1.

${ }^{13}$ Op. Cit, Boedi Harsono, Hukum Agraria Indonesia, Sejarah Pembentukan., hal. 7. 
From these various concepts, the authors conclude that the procurement of land cannot occur if there is no appropriate compensation provided by the party holding the land.

The notion of public interest is meant to be intended for the purposes, needs or interests of the people or a broad purpose. ${ }^{14}$ The question is what is meant by the interests of the people or a broad purpose? According to the prevailing laws and regulations, the term "public interest" is governed in Article 1 paragraph 6 of Law No. 2 of 2012 on Land Procurement for Development in the Public Interest "The Public Interest is the interest of the nation, the State, and the society which must be realized by the government and used as much as possible for the welfare of the people ". The definition of public interest is regulated in Article 1 point 6 of Presidential Regulation No. 71 of 2012 on Implementation of Land Procurement for Development in the Public Interest, namely "Public Interest is the interests of the nation, the State, and the society that the government must realize and use as much as possible for the welfare of the people."

Although in the legislation has mentioned the definition of "public interest", but in the implementation of the understanding is easily misunderstood, so easy to cause land acquisition in an arbitrary way if not properly guarded. Therefore, according to Mertokusumo, in taking the policy of land acquisition for the public interest, it must uphold the principles of democracy and uphold human rights by taking into account ${ }^{15}$ :

1. Land Acquisition is a legal act which results in the loss of a person's physical or non-physical rights and loss of property for a time or forever;

2. Indemnify losses must take into account: loss of rights to land, buildings, crops, loss of income and other living resources, assistance to move to another location by providing new local alternatives equipped with adequate facilities, income recovery assistance to achieve equivalent conditions with circumstances before the take;

3. Those who are displaced by land acquisition should be accounted for in compensation should be expanded;

4. To obtain accurate data on those affected by evictions and the amount of compensation for absolute undertaken basic and socioeconomic surveys;

5. It is necessary to apply the agency responsible for execution and resettlement implementation;

6. Ways of deliberation to reach agreement must be developed;

7. Needs a means of collecting complaints and settling disputes arising in the process of land acquisition.

${ }^{14}$ Oloan Sitorus dan Dayat Limbong, Pengadaan Tanah Untuk Kepentingan Umum, (Yogyakarta: Mitra Kebijakan Tanah Indonesia, 2004), hal. 6

15 Abdurahman H, Masalah Pencabutan Hak-Hak Atas Tanah Dan Pengadaan Tanah Bagi Pelaksanaan Pembangunan Untuk Kepentingan Umum Di Indonesia, (Bandung: PT. Citra Aditya Bakti, 1996), hal. 107. 


\section{Discussion}

\subsection{Implementation of Law Number 2 Year 2012 on Land Procurement for Development in the Public Interest in order to provide Human Rights Protection to Victims of Eviction}

One of the principles of the rule of law is the guarantee of human rights abuses. One of the basic rights of human is protection of property rights to a land. Law Number 2 Year 2012 on Land Procurement for Development in the Public Interest is one of the reasons to uphold one of the principles of the rule of law, namely to protect human rights in the field of land ownership rights, therefore the procurement of land by both the central government and regional government can no longer do so arbitrarily without rights without procedures and ordinances imposed by law, including the provision of compensation for the land held in an unfair and fair manner to the party entitled.

Article 1 Sub-Article 2 states that the Land Agency is to provide land by providing compensation that is fair and fair to the party entitled. When looking closely at the article, it can be concluded that the procurement of land can only occur if the lands that have been held have been given compensation and fair damages to the party entitled. Subsequently, in the Act mentioned in Article 13, the procurement of land for public interest is held with the following stages: (a) planning; (b) preparation, (c) implementation, and (d) delivery of results. Given these stages, both central and local governments are required to comply with the procedures and stages of land acquisition prior to disposal of community ownership rights. Moreover, when looking at the article, the stages are imperative, meaning that if one of the stages is not done or both stages are not done sequentially, then the process of land procurement can be judged null and void due to defect procedure.

The first stage is the planning stage. The planning stage referred to here is the stage where the Institution (Government / BUMN / BUMD / Private) requiring the land to be held makes a plan based on the Spatial Plan and the development priorities listed in the Medium Term Development Plan, the Strategic Plan, the Work Plan The Government of the Agencies concerned. ${ }^{16}$ Then thereafter prepare a Planning Document containing: (a) the purpose and objectives of the development plan; (b) compliance with the Spatial Plan and the National and Regional Development Plans; (c) the location of the land; (d) the required land area; (e) an overview of the status of the land; (f) estimated time of Land Procurement; (g) the estimated period of development implementation; (h) the estimated value of the land; and (i) budgeting plans. ${ }^{17}$ Then to the document is prepared based on feasibility studies and then set by the agency (government) that is require ${ }^{18}$ and the document file submitted to the Provincial Government. ${ }^{19}$

16 Pasal 14 ayat (1) dan (2) Undang-Undang Nomor 2 Tahun 2012 tentang Pengadaan Tanah untuk Pembangunan Demi Kepentingan Umum.

${ }^{17}$ Pasal 15 ayat (1) Undang-Undang Nomor 2 Tahun 2012 tentang Pengadaan Tanah untuk Pembangunan Demi Kepentingan Umum.

18 Pasal 15 ayat (2) dan (3) Undang-Undang Nomor 2 Tahun 2012 tentang Pengadaan Tanah untuk Pembangunan Demi Kepentingan Umum.

${ }^{19}$ Pasal 15 ayat (4) Undang-Undang Nomor 2 Tahun 2012 tentang Pengadaan Tanah untuk Pembangunan Demi Kepentingan Umum. 
The second stage is the preparation stage. The preparatory stage here is a follow-up after the planning phase is completed, where the provincial government as the party who has received the land procurement document, carrying out the following activities, among others ${ }^{20}$ : (a) notification of the development plan means the provincial government shall notify the public regarding the land acquisition plan for development in the interest of the public either directly face to face or notification by mail, (b) initial data collection of development plan location means the provincial government to collect data on the community along with the object of land affected by the procurement of land. (c) the public consultation of the development plan means that the provincial government meets directly with the community directly explaining the procurement of land for development in the public interest, whereby the provincial government has been able to issue a decree (beschikking), which in practice against the decree is often filed to the Court to be sued because the provincial government sometimes unilaterally issued the decree without approval by the entire community affected by the procurement of the land.

The third stage is the implementation stage of land procurement, ${ }^{21}$ which means that the authority of this phase of implementation is no longer the authority of the provincial government, but the authority of the land agency (Badan Pertanahan Nasional / BPN) to carry out activities is based on the Decision Letter of Determination of Location for Development such as: (a) an inventory and identification of the ownership, ownership, use and utilization of the land of the held land; (b) make an assessment of damages; (c) deliberation of indemnification mechanism; (d) indemnification; and (e) Release of Institution Land. In practice, assessments of damages may be assessed by an appraiser, or based on consensus deliberations between the community and the provincial government or by a permanent court decision.

The fourth stage is the Delivery of Land Procurement ${ }^{22}$ which is also still the authority of the Land Agency (Badan Pertanahan Nasional / BPN) which, if the stages of the government of compensation has been implemented by granting the right directly or through the court in the court, the Land Agency (Badan Pertanahan Nasional / BPN) is obliged to surrender the land which has been held to the agency requiring the land for public purposes.

With the enactment of Law No. 2 of 2012 on Land Procurement for Development in the Public Interest, it indirectly avoids the practices of arbitrariness to be undertaken by parties who will conduct land procurement activities on the basis of public interest, so against the right of ownership cannot be deprived or repealed in an arbitrary manner by the authorities.

\subsection{Legal Consideration of the Panel of Judges of the State Administrative Court of Jakarta In Decision Number 59 / G / 2016 / PTUN-JKT That Cancels the Determination of Location for Development in the Public Interest by the Provincial Government of DKI Jakarta}

\footnotetext{
${ }^{20}$ Pasal 16 Huruf (a), (b) dan (c) Undang-Undang Nomor 2 Tahun 2012 tentang Pengadaan Tanah untuk Pembangunan Demi Kepentingan Umum.

${ }^{21}$ Pasal 27 Undang-Undang Nomor 2 Tahun 2012 tentang Pengadaan Tanah untuk Pembangunan Demi Kepentingan Umum.

${ }^{22}$ Pasal 48 Undang-Undang Nomor 2 Tahun 2012 tentang Pengadaan Tanah untuk Pembangunan Demi Kepentingan Umum.
} 
One of the concrete cases of land acquisition for development in the public interest by using Law No. 2 of 2012 is a case that occurred in the Village Bidara Cina, District Jatinegara, East Jakarta started when the Decree of Determination Number 2779 Year 2015 issued by the Governor of DKI Jakarta is related to the establishment of Sodetan Inlet by the Provincial Government of DKI Jakarta (Governor) on the basis of public interest. According to Chinese citizens affected by the development of Sodetan inlet, ${ }^{23}$ they were never informed in connection with the issuance of the Decision Letter of Determination of Location Number 2779 of 2015, so they filed a lawsuit at the Jakarta State Administrative Court to annul the Letter of Decision (beschikking).

As for the reasons in filing the lawsuit that is the procedure of issuance of Decision Letter Determination Location 2779 Year 2015 contradict with Law No. 2 of 2012 on Land Procurement for the Development of Public Interest and Presidential Regulation No. 71 of 2012 on President Number 71 Year 2012 on Implementation of Land Procurement for Development for Public Interest which in essence in the regulation requires the procurement of land for development in the interests of generally carried out by stages (a) planning; (b) preparation, (c) implementation, and (d) delivery of results.

As for the fact according to the residents, the Provincial Government of DKI Jakarta at least before issuing the Decision Letter of Location Determination has never done such things as showing its land procurement planning document, then, not having an AMDAL (Environmental Impact Analysis), never conducting proper public consultation activities with a plan of inlet development in which the community meet directly with the community, and not related to the amount of compensation received by the affected people.

The lawsuit in Jakarta's administrative court has been terminated with a Decision Number: 59 / G / 2016 / PTUN-JKT which won the citizen of Jakarta caste Bidara Cina. when examining the legal considerations of the Panel of Judges who hear the case, the judges concluded if the Local Determination of Location conducted by the Provincial Government of DKI Jakarta is not in accordance with the legal procedures of Law Number 2 Year 2012 and Presidential Regulation No. 71 Year 2012, especially the non-implementation of procedures ) planning; (b) the preparation, (c) the implementation, and (d) the delivery of the results in its land procurement activities so that the Decree of Determination of Location Number 2779 of 2015 shall be canceled. The judges' considerations are as follows:

"Considering that, when reading the provisions relating to the stages of development planning and the preparation stage of development up to the establishment of the construction site, the Court is of the opinion that the provision is cumulative is not an alternative meaning that the government prior to establishing the construction site shall follow all procedures specified in the stages of development planning as well as in the preparation stage of development, so that the non-fulfillment of any of the procedures prescribed in that provision causes the determination of the location stipulated by the governor to be void;

"Considering that if the provision relating to the stages of development planning and the preparation stage of development in this dispute is related to the

\footnotetext{
${ }^{23}$ Wawancara langsung dengan Resa Indrawan Samir, SH, MH selaku Kuasa Hukum Masyarakat Keluarahan
} Bidara Cina, Jakarta Timur tertanggal 15 Februari 2018. 
fact in the hearing the Defendant has never denied and / or proven it in the hearing that the Defendant's action in issuing the a quo dispute object is inconsistent with the procedure as determined in the above provisions."

"Considering, that since the Defendant cannot prove the a quo Dispute Object issued in accordance with the procedure stipulated in the applicable law provisions, therefore the Plaintiffs have successfully proven the arguments of the lawsuit so the Plaintiffs' claim shall be entitled to be granted in its entirety."

When looking at the considerations of the judges of the judges, it can be concluded if the procedure of determining the location for development in the public interest must fulfill the conditions stipulated by Law Number 2 Year 2012 on the Determination of Location for Development in the Public Interest and to the requirements of procurement procedure the land stipulated in the legislation is cumulative, meaning that the non-compliance of one of the requirements or procedures for land acquisition, then the procurement of the land is null and void. according to the opinion of the author, it is reasonable that the judge to interpret the land acquisition legislation is cumulative and not an alternative, because the judge tries so that the act of procurement of land in Indonesia is not arbitrary and contains the principle of prudence, because the protected in the procurement of the land is a right community law, namely ownership rights that are easily eliminated on the basis of land acquisition in the public interest.

\section{Closing}

\subsection{Conclusion}

a) Law No. 2 of 2012 on Land Procurement for Development For the Public Interest can only be applied and provides Human Rights Protection to Victims of Eviction if all stakeholders involved especially those who have authority over the procurement of land such as Provincial Government and National Land Agency adhere to all procedures for land acquisition procedures (a) planning; (b) preparation, (c) implementation, and (d) delivery of results;

b) Decision of the Jakarta State Administrative Court Judge On Decision Number 59 / G / 2016 / PTUN-JKT Decision Number 5179 Year 2015 issued by the Governor of DKI Jakarta related to the establishment of Sodetan Inlet by the Provincial Government of DKI Jakarta (Governor ) on the basis of the public interest explain if Public Officials involved in the procurement of land shall not violate Law No. 2 of 2012 on Land Procurement because the infringing act is an arbitrary measure that could reduce the principles of legal protection of human rights related to the ownership rights of citizens.

\subsection{Suggestions}

a) For the enforcement of the principles of legal protection for the human rights of citizens in Indonesia in relation to their ownership rights, any act of land acquisition conducted by the competent authority needs to be supervised by the superior, in order that the competent authority is more careful in carrying out its authority; 
b) In addition, there should be strict witnesses to officials who have taken land acquisition actions, but their land procurement actions are proven to be unlawful or arbitrary either based on court decisions or superior assessments.

\section{References}

\section{Books, Articles, Papers:}

[1]. Abdurahman H, Masalah Pencabutan Hak-Hak Atas Tanah Dan Pengadaan Tanah Bagi Pelaksanaan Pembangunan Untuk Kepentingan Umum Di Indonesia, Bandung: PT. Citra Aditya Bakti, 1996.

[2]. Achmad Rubaie, Hukum Pengadaan Tanah Untuk Kepentingan Umum, Malang: Bayumedia Publishing, 2007.

[3]. AP. Parlindungan, Bunga Rampai Hukum Agraria Serta Land Reform, Bandung: Mandar Maju, 1994.

[4]. Bernhard Limbong, Pengadaan Tanah untuk Pembangunan, Jakarta: Marghareta Pustaka, 2015.

[5]. Boedi Harsono, Hukum Agraria Indonesia Sejarah Pembentukan Undang-Undang Pokok Agraria, Isi dan Pelaksanaannya, Jakarta: Jembatan, 2005.

[6]. —_ Menuju Penyempurnaan Hukum Tanah Nasional, cet. 3., Jakarta: Universitas Trisakti, 2007.

[7]. Ida Nurlinda, Prinsip-Prinsip Pembaharuan Agraria Perspektif Hukum, Jakarta: Rajawali Press, 2009.

[8]. Imam Koeswahyono, Melacak Dasar Konstitusional Pengadaan Tanah Untuk Kepentingan Umum (Artikel, 2008).

[9]. Mahrus Ali dan Syarif Nurhidayat, "Penyelesaian Pelanggaran HAM Berat In Court System dan Out Court System", Depok: Gramata Publishing, 2011.

[10].Mudakir Iskandar, Pembebasan Tanah Untuk Pembangunan Kepentingan Umum, Jakarta: Permata Aksara, 2015.

[11].Oloan Sitorus dan Dayat Limbong, Pengadaan Tanah Untuk Kepentingan Umum, Yogyakarta: Mitra Kebijakan Tanah Indonesia, 2004.

[12].Soerjono Soekanto \& Sri Mamudji, Penelitian Hukum Normatif Suatu Tinjauan Singkat, Jakarta: Rajawali, 1990.

[13].Tampil Anshari Siregar, Pendalaman tanah UUPA, Jakarta: Pustaka Bangsa Press, 2005.

[14].Yusriadi, Industrialisasi \& Perubahan Fungsi Sosial Hak Milik Atas Tanah, Yogyakarta: Genta Publishing, 2010.

\section{Court Decisions, Interviews and Laws and Regulations:}

[1]. Putusan Mahkamah Konstitusi Nomor 002/PUU-I/2003, tertanggal 21 Desember 2004, terkait Sumber Daya Alam (SDA).

[2]. Keputusan Presiden Nomor 55 Tahun 1993 tentang Pengadaan Tanah Bagi Pelaksanaan Pembangunan Untuk Kepentingan Umum.

[3]. Peraturan Presiden Nomor 36 Tahun 2005 tentang Pengadaan Tanah Bagi Pelaksanaan Pembangunan Untuk Kepentingan Umum.

[4]. Peraturan Presiden Nomor 71 Tahun 2012 tentang Presiden Nomor 71 Tahun 2012 tentang Penyelenggaraan Pengadaan Tanah Bagi Pembangunan Untuk Kepentingan Umum.

[5]. Undang-Undang Nomor 2 Tahun 2012 tentang Pengadaan Tanah untuk Pembangunan Demi Kepentingan Umum.

[6]. Wawancara langsung dengan Resa Indrawan Samir, SH, MH selaku Kuasa Hukum Masyarakat Keluarahan Bidara Cina, Jakarta Timur tertanggal 15 Februari 2018. 